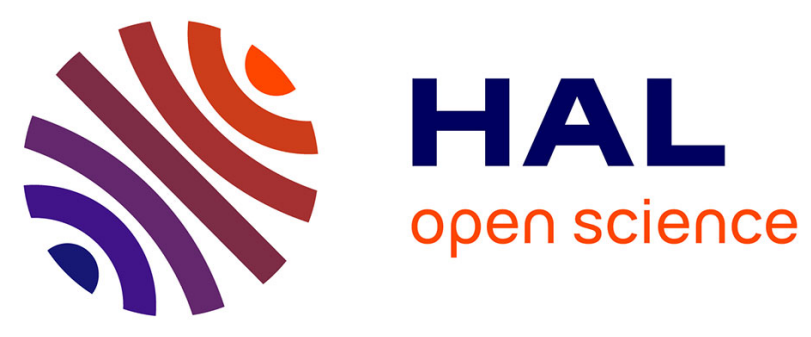

\title{
Port Performance Measures in Brazil: An Analysis in Port of Santos
}

Renato Santos, João Gilberto Mendes dos Reis, Júlio Cesar Raymundo, Emerson Rodolfo Abraham, Ataide Pereira Cardoso Junior, Aguinaldo Souza

\section{- To cite this version:}

Renato Santos, João Gilberto Mendes dos Reis, Júlio Cesar Raymundo, Emerson Rodolfo Abraham, Ataide Pereira Cardoso Junior, et al.. Port Performance Measures in Brazil: An Analysis in Port of Santos. IFIP International Conference on Advances in Production Management Systems (APMS), Sep 2019, Austin, TX, United States. pp.180-186, 10.1007/978-3-030-30000-5_24 . hal-02419229

\author{
HAL Id: hal-02419229 \\ https://hal.inria.fr/hal-02419229
}

Submitted on 19 Dec 2019

HAL is a multi-disciplinary open access archive for the deposit and dissemination of scientific research documents, whether they are published or not. The documents may come from teaching and research institutions in France or abroad, or from public or private research centers.
L'archive ouverte pluridisciplinaire HAL, est destinée au dépôt et à la diffusion de documents scientifiques de niveau recherche, publiés ou non, émanant des établissements d'enseignement et de recherche français ou étrangers, des laboratoires publics ou privés.

\section{(c)(1)}

Distributed under a Creative Commons Attribution| 4.0 International License 


\title{
Port Performance Measures in Brazil: An Analysis in Port of Santos
}

\author{
Renato Márcio dos Santos ${ }^{1[0000-0001-6100-752 X]}$, João Gilberto Mendes dos \\ Reis 2[0000-0001-6409-2299], Júlio Cesar Raymundo3[0000-0001-7383-7520], \\ Emerson Rodolfo Abraham 4[0000-0001-6500-6989], Ataide Pereira Cardoso \\ Junior ${ }^{5[0000-0001-7754-0513], ~ a n d ~ A g u i n a l d o ~ E d u a r d o ~ d e ~}$ \\ Souza $6[0000-0001-6100-752 X]$ \\ Paulista University - UNIP, PPGEP, São Paulo, Brazil \\ Email: renato@dnadosaber.com.br
}

\begin{abstract}
Competitiveness of Brazilian agribusiness depends on the capacity to sell products through the largest port in South America, Santos. The aim of this paper is to analyze the port efficiency indicators of Brazilian National Waterways Transportation Agency regarding the Port of Santos. To this end, we collected the indicator of port for handling, service time, and tariffs (fee) during of period of 2016-2018 and analyzed using time series. The results showed a tendency of slight growth for handling, moderate growth for the tariff, and a slight decrease in the service time.
\end{abstract}

Keywords: Logistics, Port Performance indicators, Bulk Cargo, International Trade

\section{Introduction}

Population growth has boosted world consumption making logistics one of the main elements of global supply chains [1]. The world trade is highly dependent on maritime transportation due to cargo capacity and associated costs.

Maritime transportation depends on the existence of ports of cargo with a capacity to attend ships of different sizes and move the big volume of these commodities.

In Brazil, for instance, ports play a key role in international trade [2] where port terminals handled over $90 \%$ of the total cargo throughput in 2014 for foreign trade [3].

Despite this importance, the Brazilian ports lack policies for the sector and financial resources for new investments, the terminals, and port equipment are obsolete and inefficient, and costs are higher [4].

In Port of Santos, this reality is not different. Even being the main Brazilian port [2] and responsible for the most amount of Brazilian commodities exportation, agricultural handling is affected by the lack of efficiency of the Port.

To face this problem the country promulges two laws of port modernization (1993 and 2013) and established a National Agency to regulate the port activity. 
As a result, it was adopted operational and financial indicators to measure port performance based on the indicators of the United Nations on Conference and Trade Development (UNCTAD). However, is it possible to predict the behavior of these indicators along of time to define port strategy?

To answer this question the aim of this article consists of the application of time series method to verify if is feasible to predicate the behavior of the indicators established by ANTAQ to measure the efficiency of Brazilian ports. To do so, we collected bulk handling, service time, and port tariff from Port of Santos provided by ANTAQ during the period of 2016-2018. The results showed a tendency of slight growth for handling (cargo handling), moderate for tariff, and a decrease in the service time.

\section{Port Performance Measurements}

The measurement of port performance is relevant for port users, policy makers, port developers and other stakeholders [5]. Companies and policy makers can use them to improve port efficiency in order to respond to the demand of international markets.

Around 80 percent of world goods are transported by sea, thus port efficiency has a direct impact on the ability of countries export and import products [6]. In the case of developing countries, this value represents 90 percent, hence, local ports need to operate efficiently to allow them to integrate into the world economy.

In 1976 Unctad (United Nations on Conference and Trade Development) [7] developed a comprehensive system of indicators to measure port performance divided in two folds: (i)financial indicators: Tonnage worked (tons), berth occupancy revenue per ton of cargo (monetary units/ton), Cargo-handling revenue per ton of cargo (monetary units/ton), labour expenditure per ton of cargo (monetary units/ton), capital equipment expendidture per ton of cargo (monetary units/ton), total contribution (monetary units); (ii) Operational indicators: arrival late (ships/day), waiting time (hours/ship), service time (hours/ship), turn-round time (hours/ship), tonnage per ship (tons/ship), fraction of time berthed ships worked, number of gangs employed per ship per shift (gangs), tons per ship-hour in port (tons/hour), tons per ship-hour at berth (tons/hour), tons per gang hour (tons/gang-hour), fraction of time gangs idle.

Chung [8] in 1993 dealing with performance indicators suggests that operational performance of port is generally measured in terms of the speed with vessels is despatched while financial indicators are defined based on usual financial statements as the income statement, profit and loss account, and balance sheet. Since then other studies have been extended the knowledge revolving around port performance $[9,10,11,12]$.

In Brazil, the first law for port modernization to reduce costs and improve competitiveness was created in 1993 and changed in 2003 for a new one that just confirmed the main questions involving port performance [2]. However, Galvão et al. point out the Brazilian ports cargo throughput decreased between 
2013 and 2015, and the foreign trade flow in value has diminished by almost $20 \%$ between 2013 and 2015 [2].

The Brazilian National Waterway Transportation Agency was established in 2001 a system for measure performance of Brazilian ports considering financial and operational indicators according to the Unctad recommendations. These indicators are monthly handling in the port of Santos, average board, and berthing rate [13]. We used ANTAQ indicators available to evaluate port efficiency regarding the grains exports. The methodology section presents the details os the research.

\section{Methodology}

This research is an exploratory case of Brazilian port efficiency. The aim of the research was to evaluate the port indicators used by the National Waterway Transportation Agency regarding bulk cargo during the period of 2016 - 2018 [13]. In this respect, the study analyzes three performance indicators: monthly handling in the port of Santos (handling), average board (service time), and berthing rate (fee).

The data were collected of ANTAQ database [13] and processed using MS Excel@ software to calculate time series. Time series analysis has been paid close attention due to the exponential growth of time-stamped data, such as economics and finance [14].

The functions tested in this research were: linear, exponential, polynomial of the 2nd degree, power, and logarithmic (classical methods).

\section{Results}

Given that time series methodology Table 1 shows the functions chosen for each series, according to the highest coefficient of determination or regression measure (R2). Values closer to 1 indicate a greater correlation between the dataset and serve as indicators for choosing the most adequate functions for predictions [15].

Table 1: Determination coefficient

\begin{tabular}{|c|c|c|c|}
\hline Equations & Handling & Service time & Fee \\
\hline Exponential & 0.0128 & 0.0280 & 0.101 \\
\hline Linear & 0.0087 & 0.0405 & 0.138 \\
\hline Logarithmic & 0.009 & 0.0261 & 0.017 \\
\hline Power & 0.0103 & 0.0216 & 0.009 \\
\hline Polynomial 2 & 0.0087 & 0.0409 & 0.519 \\
\hline
\end{tabular}

For the handling the best model was the exponential one, being that for medium board and mooring rates the polynomial model of 2 greatness. Table 
2 indicates the trend functions provided by the software after selection, using the coefficient of determination shown in Table 1.

Table 2: Trend equations

\begin{tabular}{|c|c|c|}
\hline Index & Equations & AMPE \\
\hline Handling & $4 E+06 e 0.0024 x 0.0128$ & $18 \%$ \\
\hline Service time & $-0.0303 x 2-1.5618 x+716.340 .0409$ & $26 \%$ \\
\hline Fee & $152.55 x 2-4794.2 x+1883030.5187$ & $8 \%$ \\
\hline
\end{tabular}

The mean absolute error is an indicator of the variations in the forecasts shown in the results section. This indicator was calculated by means of the average between the original and predicted values of each period studied.

\section{Discussion}

The Port of Santos bulk handling between 2016 and 2018 showed an exponential behavior, registering an average growth of approximately 500 thousand tons, Figure 1.

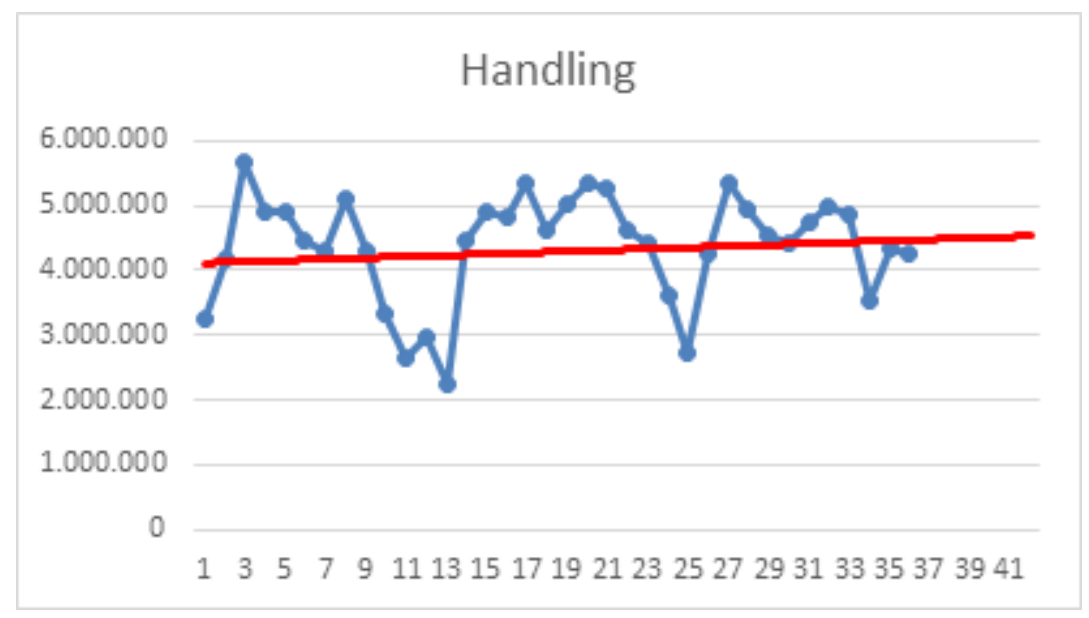

Fig. 1: B = Monthly handling behavior in Santos from January 2016 to December 2018 in tons.

As depicted in Figure 1 a slight growth trend occur for the handling of this port with a projection of 4.4 million tons. However, when considering the charges applied for mooring in the same period to operate ships that moved 
cargo in bulk, there is an average value of BRL 154,709 equivalent to $(\$ 40,184)$ per vessel at a rate of conversion of BRL 3.85 until June 2019.

Figure 2 presents the behavior of mooring rates in the Port of Santos from January 2016 to December 2018 in BRL.

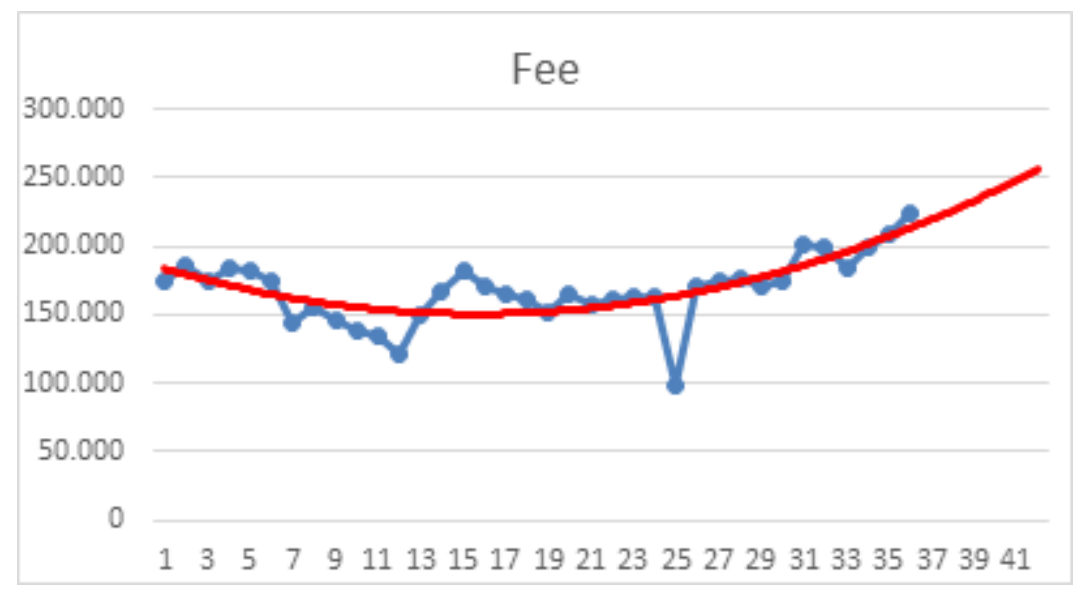

Fig. 2: Rate per mooring from 2016 to 2018.

As can be seen in Figure 2 there is a growth in the tariff practiced, and a forecast of BRL 256,045 equivalent to $(\$ 66,505)$ for June 2019 , a growth of $12.7 \%$ in 6 months. While the handling and rate indicators are on the rise, service level indicators, such as the average board, are not so encouraging, as these showed a downward trend for subsequent months, Figure 3.

Although the tariff and handling showed an optimistic scenario with an estimated growth, the same did not occur in the service level of the port of Santos, which showed a slight decrease of $3.9 \%$ in its average board index, estimating the mark of 597 that is lower than the previous indices (Table 3).

Table 3: Forecasting

\begin{tabular}{lcccccc}
\hline Index & Jan & Feb & Mar & Apr & May & Jun \\
\hline Handling & $4,371,448$ & $4,381,952$ & $4,392,482$ & $4,403,036$ & $4,413,616$ & $4,424,222$ \\
Service time & 617 & 613 & 609 & 605 & 601 & 597 \\
Fee & 219,759 & 226,406 & 233,358 & 240,615 & 248,177 & 256,045 \\
\hline
\end{tabular}

Table 3 shows the projections made for each indicator based on the historical series that based our forecasts that are explained in this article. 


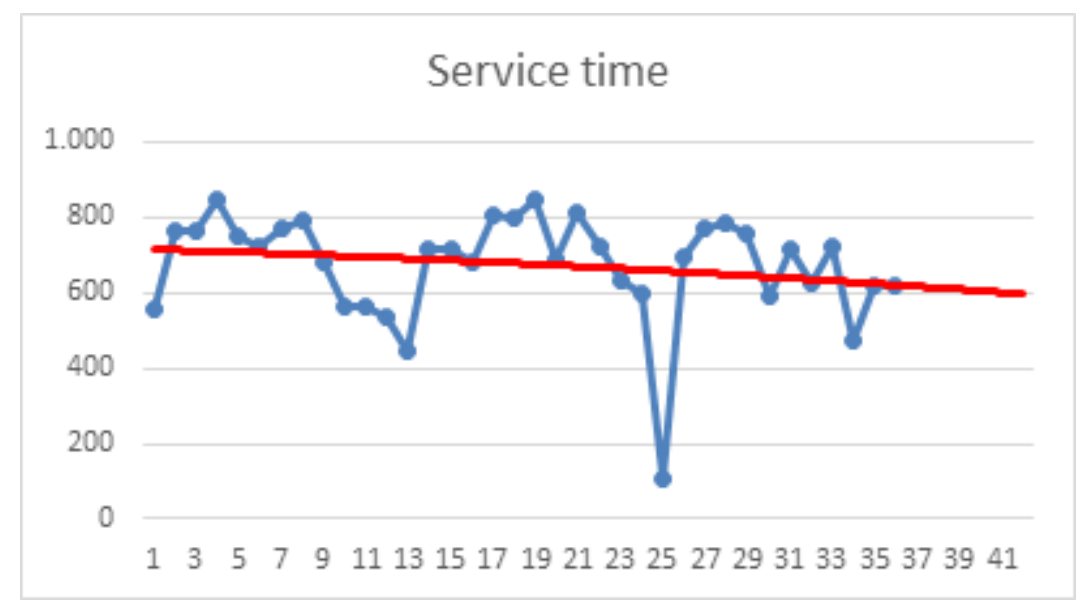

Fig. 3: Average plank rates of the port of Santos in the period from 2016 to 2018.

\section{Conclusion}

The present study analyzed Port Performance Measures of Brazilian National Waterway Transportation Agency for the Port of Santos. The main contribution of this study is to validate the use of these indicators as a measure to improve port efficiency. In this sense, we adopted a time series method.

Our results showed predictability in the handling and tariff indicators, which may bring greater confidence to the sector. In further studies intents to analyze other Brazilian ports, other products and alternative methods to time series.

\section{References}

1. de Lima, D.P., Fioriolli, J.C., Padula, A.D., Pumi, G.: The impact of Chinese imports of soybean on port infrastructure in Brazil: A study based on the concept of the Bullwhip Effect. Journal of Commodity Markets 9, 55-76 (2018), https: // linkinghub.elsevier.com/retrieve/pii/S2405851316301106

2. Galvão, C.B., Robles, L.T., Guerise, L.C.: 20 years of port reform in Brazil: Insights into the reform process. Research in Transportation Business \& Management 22, 153-160 (Mar 2017), https://1inkinghub.elsevier.com/retrieve/ pii/S2210539517300111

3. Wanke, P., Falco, B.B.: Cargo allocation in Brazilian ports: An analysis through fuzzy logic and social networks. Journal of Transport Geography 60, 33-46 (Apr 2017), https:// linkinghub.elsevier.com/retrieve/pii/S0966692316304938

4. Uderman, S., Rocha, C.H., Cavalcante, L.R.: Modernization of the port system in Brazil: a methodological proposal. Journal of Transport Literature 6(1), 221-240 (2012)

5. de Langen, P.W., Sharypova, K.: Intermodal connectivity as a port performance indicator. Research in Transportation Business \& Management 8, 97 - 102 (2013), http : //www.sciencedirect.com/science/article/pi i/S2210539513000692, port Performance and Strategy 
6. UNCTAD: Port Management Case Studies 2015-2016 Cycle of the TrainForTrade Port Management Programme English-speaking Network. Tech. rep., United Nations, New York and Geneva (2018)

7. UNCTAD: Port Performance Indicators, TD/B/C.4/131/Supp.1/ Rev. 1. Tech. rep., United Nations, New York / US (1976)

8. Chung, K.C.: Port Performance Indicators. Tech. rep., World Bank, Washington D.C. (1993)

9. Woo, S.H., Pettit, S., Beresford, A.K.C.: Port evolution and performance in changing logistics environments. Maritime Economics \& Logistics 13(3), 250-277 (Sep 2011), https: / / doi .org/10.1057/mel.2011.12

10. Pallis, A.A., Vitsounis, T.K., De Langen, P.W., Notteboom, T.E.: Port Economics, Policy and Management: Content Classification and Survey. Transport Reviews 31(4), 445-471 (Jul 2011), http: / / www. tandfonline.com/doi/abs/10 . 1080/01441647. 2010.530699

11. Ha, M.H., Yang, Z.: Comparative analysis of port performance indicators: Independency and interdependency. Transportation Research Part A: Policy and Practice 103, 264-278 (Sep 2017), http://www.sciencedirect.com/science/article/ pi i / S0965856417303701

12. Ha, M.H., Yang, Z., Notteboom, T., Ng, A.K., Heo, M.W.: Revisiting port performance measurement: A hybrid multi-stakeholder framework for the modelling of port performance indicators. Transportation Research Part E: Logistics and Transportation Review 103, 1-16 (Jul 2017), https: / / linkinghub .elsevier .com/ retrieve/pii/S1366554516308377

13. ANTAQ: http://web.antaq.gov.br/Anuario/

14. Wang, H., Zhang, Q., Wu, J., Pan, S., Chen, Y.: Time series feature learning with labeled and unlabeled data. Pattern Recognition 89, 55 - 66 (2019), http: / /www. sciencedirect.com/science/article/pii/S0031320318304473

15. Escolano, N.R., Espin, J.J.L.: Econometra: Series temporales y modelos de ecuaciones simultneas. Editorial UMH, Alacant (2016) 